\title{
ONLINE LISTENING COMPREHENSION LEARNING PROBLEMS ON SEMESTER I AND III STUDENTS AT ACADEMY OF FOREIGN LANGUAGE BALIKPAPAN
}

\author{
Era Wahyu Ningsih ${ }^{1}$, Suzanna Widjajanti ${ }^{2}$ \\ ${ }^{1,2}$ Akademi Bahasa Asing Balikpapan \\ Email: En29426@gmail.com
}

\begin{abstract}
This research was conducted to find out the problems encountered in online Listening comprehension lectures during the student pandemic at the Balikpapan Foreign Language Academy semester I and III and to find out the methods used by students in overcoming the problems they faced, this field research was conducted at the Balikpapan Foreign Language Academy, with the research subjects being all first and third semester students who have attended Listening Comprehension lectures for approximately one semester. This study used descriptive qualitative methods with data collection using observation, literature review and interviews involving first and third semester students consisting of 25 students, 6 male students and 19 female students. The collecting data using observation, literature review and interviews as a complement to the required data, from all data collection activities it was concluded that students who took part in lecture activities at the Balikpapan Foreign Language Academy in the listening comprehension course had all studied English with 3 months to With 15 years, ABA Balikpapan students have experience problems in the online learning process, especially listening comprehension courses, including unsupported internet networks, audio that cannot be heard clearly, noise from the environment around the lecturer or the students themselves, interference from devices that sometimes error and often forget the existing tasks. This study lasted approximately 4 (four) months, starting from data collection to writing research reports and from the results of this study. The implication of the study for teacher of Listening Comprehension, all the problems mentioned in this study should be identified and should be minimized prior to conducting the class to gain maximum output, for the students, they need to have a free audio disturbance environment when attending the listening comprehension class online.
\end{abstract}

Keyword: Listening, Comprehension, Audio, Online, Lecture

(c) (i)

This work is licensed under Creative Commons Attribution License 4.0 CC-BY International license

\section{INTRODUCTION}

\subsection{Introduction}

The Covid 19 pandemic has lasted for about a year and we are still asked to be vigilant even though some areas have experienced a decline in sufferers and the increase in the number of recovered patients continues to grow, before the spread occurred widely throughout the world, 
this virus was first discovered in Hubei province, Wuhan City, China in month December 2019, this was recorded in a report which stated that there was a spread of a virus called Severe Acute Respiratory Syndrome Coronavirus-2 (SARRS-CoV-2) with symptoms resembling pneumonia and the infection was spreading very quickly throughout the world. Reporting from BBC News, China itself officially reported to the WHO (World Health Organization) that the presence of this virus in their country was in December 2019.

This Research disease is caused by a corona virus which is part of the virus that causes flu and also Middle East Respiratory Syndrome (MERS-Co V) and Severe Acute Respiratory Syndrome (SARS-Co V). (Susanthi, 2021). During the current year during the Covid-19 pandemic, all sectors of human life were greatly affected, some activities had to be restricted not to meet in person, education was carried out online starting from the elementary school level to higher education. This policy must indeed be taken by the government to protect the public from being exposed to Covid-19, the regulation is stated in the circular letter of the Minister of Education and Culture (Mendikbud) Nadiem Anwar Makarim Number 4 of 2020 concerning the Implementation of Education in the Coronavirus Disease (Covid-19) Emergency Period. This disease is caused by a corona virus which is part of the virus that causes flu and also Middle East Respiratory Syndrome (MERS-Co V) and Severe Acute Respiratory Syndrome (SARS-Co V). 2021). During the current year during the Covid-19 pandemic, all sectors of human life were greatly affected, some activities had to be restricted not to meet in person, education was carried out online starting from the elementary school level to higher education. This policy must indeed be taken by the government to protect the public from being exposed to Covid-19, the regulation is stated in the circular letter of the Minister of Education and Culture (Mendikbud) Nadiem Anwar Makarim Number 4 of 2020 concerning the Implementation of Education in the Coronavirus Disease (Covid-19) Emergency Period.

With the implementation of online learning, several problems or obstacles faced by teachers and students emerged. Online activities are very difficult things to do especially for foreign language learners because the teaching and learning process is an activity that is worthy of educative, educational value interactions that occur between educators and students so that good social interactions are established (Kustanti, 2016) Of course, social interaction is easier to establish if it is done face-to-face or face-to-face. However, due to the pandemic situation and conditions, teachers and students have to adapt to the existing conditions, for foreign language learners it seems not an easy thing to learn this lesson because there are 4 skills that must always be learned, especially English, namely reading (reading), writing (writing), speaking (speaking), and listening (listening), for reading, writing, and speaking the possibility of this can help introduce slides which will more or less help the student understanding process, it is different with listening where listening is an activity or activity that pays attention and trying to get the meaning of something heard, it can also be said that it is a complex process that supports the brain for the meaning of the sound heard and understands language (Syam, 2012)ther opinions say Listening is the ability to IDE and understand what other people are saying. . This process involves understanding the speaker's accent or pronunciation, the speaker's grammar, vocabulary, and understanding their meaning (Mandarani, 2016), Some of the definitions above can be concluded that listening learners must be able to understand by processing what is heard to then 
give meaning, therefore listening skills are very influential on mastering a large vocabulary, pronouncing the right words and also understanding the meaning of words or sentence.

\subsection{Research questions}

Before this problem became a concern, the researcher also made observations through previous research, previous studies that discussed problems or obstacles in online listening learning had been studied by previous researchers, including (1) (Susilowati, 2020) who researched The Challenge of Online Learning in the Listening Class During the Covid-19 Pandemic (2) (Syaefullah, 2020) raised the issue of obstacles to the implementation of online learning at Riyaddul Jannah High School Jalancagak Subang. (3) (Anhusadar, 2020) regarding PIAUD Student Perceptions of Online Lectures during the Covid 19 Pandemic.

Based on the results of observations and see the need for improvement of teaching methods, a problem formulation is obtained:

1. How are the student profiles in term of the length of studying English?

2. What are the problems faced by ABA Balikpapan students in online Listening Comprehension class?

3. How do the students solve with problems that arise during Listening Comprehension class?

\subsection{Significance of the study}

This research would give contribution in teaching study especially in Listening Comprehension, it would give the contribution in theory of teaching-learning online English in Class and this research was expected gave advantages for learners about the problems that faced in English, they have awareness to learning and practice for the students, and hopefully this research becomes input for improvement of the quality English teaching and learning process in English listening comprehension.

\section{METHOD}

\subsection{Research Design}

This study uses a descriptive qualitative method where all data obtained through observation and interviews in this study will be analyzed using descriptive analysis, the source of data obtained through the research subject is considered valid as a whole, if it is felt that there are still some data deficiencies, the researcher conducts further discussions with data providers so that there is no misunderstanding in translating the data and an agreement can be made in the use of the data, defines qualitative methodology as a research procedure that produces descriptive data in the form of written or spoken words or from form of policy action (Moleong, 2002)and The goal of qualitative descriptive studies is a comprehensive summarization, in everyday terms, of specific events experienced by individuals or groups of individuals.(Lambert, 2013)

\subsection{Sample/Participants}

This research was conducted at the Balikpapan Foreign Language Academy by taking the research subjects were first and third semester students consisting of 25 students, 6 male students and 19 female students. 


\subsection{Instruments}

The collecting data using observation, literature review and interviews as a complement to the required data, from all data collection activities it was concluded that students who took part in lecture activities at the Balikpapan Foreign Language Academy in the listening comprehension. The researcher made observations by entering the first and third semester classes in listening comprehension courses at different times and places, during the observation process; the researcher takes notes and takes the required photos. To complete the research data, the researcher also analyzes through references that discuss the same problem and conducts interviews with participants by asking questions that are relevant to research needs.

\subsection{Data Analysis}

In order to obtain the required and valid data, the researcher carried out the analysis process, the steps taken were data collection, data reduction, data presentation and then conclusions were drawn. "Data analysis is the process of systematically searching and arranging the interview transcripts, field notes, and other materials that you accumulate to increase your own understanding of them and to enable you to present what you have discovered to others" (Sugiono, 2007). With this opinion, the data analysis process must be carried out in order to get the data that is really in accordance with what we need.

One of the important things in the data analysis process is that the reduction process begins with the reduction process conclude the data, then sort the data in units of certain concepts, certain categories, and certain themes. Data analysis activities the researcher uses the reduction process from Miles and Huberman, where data reduction is an effort conclude the data, then sort the data in units of certain concepts, certain categories, and certain themes. (Rijali, 2018).

\section{FINDINGS AND DISCUSSION}

\subsection{Findings and Discussion}

In this pandemic period, listening learners must be faced with online or online learning processes, from the initial field survey, several obstacles or problems were encountered during the online listening learning process. In offline learning, there are many obstacles encountered during the process, such as difficulty understanding or understanding certain English pronunciation, difficulty overcoming redundancy, difficulty predicting the language of meaning because they are not familiar with word patterns, do not understand everyday vocabulary, cannot adjust listening speed, have difficulty understanding other accents, lack the ability to use basic environmental knowledge to get meaning from the listening delivered(Fika, 2016).This statement is in accordance with the opinion(Underwood, 1990)there are several difficulties in listening for students, namely (1) listeners cannot control the speed of speech of the person delivering the message, and they feel the message conveyed is lost before they can understand the content of the message. The moment they can understand one message, at that moment another message is lost. (2) The listener does not have the opportunity to ask the speaker to repeat or clarify the message conveyed, for example when listening to the radio, watching TV, so that the listener must be able to understand what it is (3) The limited vocabulary possessed by the listener, makes the listener unable to understand the content of the text. what they hear can even make them 
bored and frustrated (4) The listener's failure to recognize and understand the 'signs' sent by the speaker that causes the listener to misunderstand the content of the message he receives (5) Error in interpreting the message received, so that the message content what is conveyed is received or interpreted differently by listeners (6) Unable to concentrate due to various things, such as uninteresting topics, physical exhaustion, noisy environment and so on. (7) Concerns about the differences in the methods and materials taught by the teacher with material heard through audio devices or native English speakers.

Because of many problems that exist, the researcher wants to find out more about the problems faced when students carry out the online listening learning process, especially students of the Balikpapan Foreign Language Academy in semesters 1 \& III, and the results of observations and initial data collection, it is known that students have studied English for a long time, this can be illustrated in the following table:

Table 1. Length of Learning English

\begin{tabular}{c|c|c|}
\hline \hline No & The Period of Study & The Number of Students \\
\hline 1. & 3 Month & 3 \\
\hline 2. & 2 Years & 1 \\
\hline 3. & 3 Years & 1 \\
\hline 4. & 7 Years & 2 \\
\hline 5. & 9 Years & 1 \\
\hline 6. & 10 Years & 1 \\
\hline 7. & 11 Years & 7 \\
\hline 8. & 12 Years & 2 \\
\hline 9. & 13 Years & 5 \\
\hline 10. & 15 Years & \\
\hline
\end{tabular}

\section{Table 2 Length of Learning English in Percent}

\section{Length of time studying English ABA Balikpapan Semester I and III of 2020}

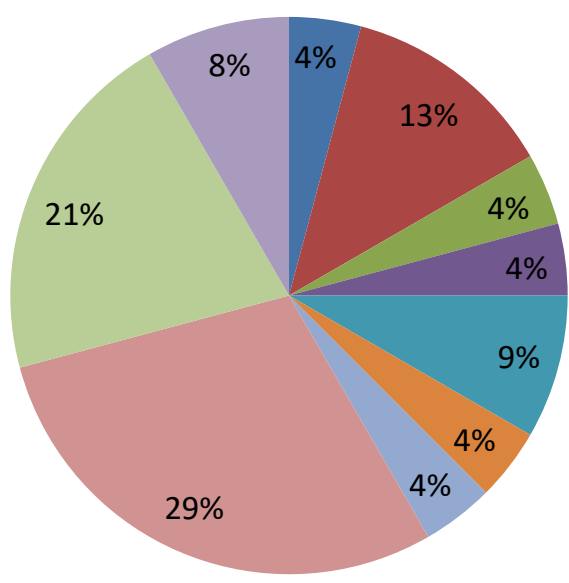

Learning Period (Year)

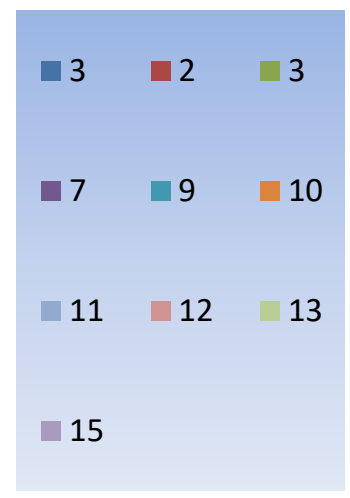


The results of data processing, it was concluded that semester 1 and 3 students on average studied English for 15 years or about 29\%, the second order they studied for 13 years or about $21 \%$, the shortest time for student learning was 3 months or about $4 \%$ the smallest number It is necessary to search for further data, so that it can be concluded that the cause of this student is just learning English with a very short range. If you observe the results of the data above, it is known that the students in the first and third semesters have studied English for 12 years at most. After getting the information above, the writer also looks for data about student opinions about whether or not listening skills are needed for foreign language learners, especially English and $100 \%$ of respondents stated that it is very necessary for various reasons including Respondents 1 , $2,5,8,13,14,16,17,21,24$ it can be concluded from their opinion that learning and listening skills are needed to make it easier to understand what other people are saying, can affect a person's listening and speaking level in order to give a good response to the other person, get used to listening the interlocutor speaks a foreign language so that in practice it can easily understand the interlocutor. Conclusion Another opinion from respondents about the importance of having listening skills is Respondents 3,4,6,7 stated that in English there are similarities in sound between one word and another so that if listening skills are low, there will be misunderstandings. The conclusion from the opinion of Respondents 9, 10, 11, 12, 20, 22, 23, by practicing listening skills it will make us accustomed to the original pronunciation and help us communicate effectively and is very helpful in adding vocabulary.

Along with the ongoing pandemic period and learning is carried out online, the researcher also asked about respondents' opinions about online listening learning whether it was effective enough in helping them learn, all respondents answered Not Effective due to various reasons including the disruption of learning with very large networks. bad, causing the audio to not be delivered properly. Furthermore, respondents also explained the problems or obstacles they encountered during online lectures. The resulting data is listed in table 3 below:

\begin{tabular}{l|c|l}
\hline No & Respondents & \multicolumn{1}{c}{ Problems } \\
\hline 1 & $1,2,4,5,6,7,9,10,11,13,14,15,18,19,20,21,22$ & $\begin{array}{l}\text { The factor of a disconnected or unstable } \\
\text { Internet network causing the sound to be } \\
\text { not clear/clear, disturbing concentration } \\
\text { when listening to audio and being } \\
\text { disconnected. }\end{array}$ \\
\hline 2. & 3 & $\begin{array}{l}\text { The audio that is issued is not clear, it } \\
\text { could be because the lecturer or student } \\
\text { device does not support it. }\end{array}$ \\
\hline 3. & $8,12,18$ & $\begin{array}{l}\text { Noise that is around the lecturer or } \\
\text { student environment or the sound of } \\
\text { audio that is not clear. }\end{array}$ \\
\hline 5. & 17 & $\begin{array}{l}\text { Unable to attend listening class because } \\
\text { of an error on the phone device, causing } \\
\text { material to be missed. }\end{array}$ \\
\hline 6. & 23 & \begin{tabular}{l} 
No Answer \\
\hline
\end{tabular} \\
\hline
\end{tabular}




\begin{tabular}{l|l|l}
\hline & $\begin{array}{l}\text { activities because the phones are } \\
\text { difficult to add applications. }\end{array}$ \\
\hline
\end{tabular}

The above data processing, various problems were found that hindered students from learning Listening online and the most inhibiting factor was the internet network which was not very supportive at all because it was unstable, suddenly disconnected and disrupted student concentration, while the internet connection in the online learning process was very necessary, because the use of the internet for learning conditions students to learn independently. (Rusman, 2009), if the network does not support it will cause further problems, as expressed by students, hampering the delivery of learning, lagging material and ultimately difficulty in doing the assigned tasks. there is.

The results of the data on problems that arise in the online learning process, the problems they face during online learning do they reduce their enthusiasm for learning, the data obtained are:

\begin{tabular}{c|c|c}
\hline No & Respondent & The Impact of the Problem \\
\hline 1 & $3,6,7,8,11,13,14,15,18,22,23$ & $\begin{array}{c}\text { Does not interfere with the learning } \\
\text { process }\end{array}$ \\
\hline 2 & $1,2,4,9,10,12,16,17,19,20,21,24$ & $\begin{array}{c}\text { Slightly interfere with the learning } \\
\text { process }\end{array}$ \\
\hline
\end{tabular}

The obstacles faced by students in online listening, some students are a little disturbed and reduce their enthusiasm for learning and some are still able to study well. Problems that occur need to be overcome so that the learning process goes well and produces maximum results, many things are done by students in doing or overcoming the problems that occur, including;

\begin{tabular}{c|c|l}
\hline No & Respondents & \multicolumn{1}{|c}{ How to Solve the Problems } \\
\hline 1. & 1,21 & $\begin{array}{l}\text { Trying to maximize the internet } \\
\text { connection network connection and } \\
\text { condition the place so that it sounds } \\
\text { clearer. }\end{array}$ \\
\hline 2. & 2 & $\begin{array}{l}\text { Self-study by repeating what everyone } \\
\text { has learned }\end{array}$ \\
\hline 5. & 4 & $\begin{array}{l}\text { By asking a lot of questions when these } \\
\text { obstacles arise, either to the lecturer } \\
\text { during the lecture, or to other friends } \\
\text { when the lecture has finished }\end{array}$ \\
\hline 6. & $5,6,7,9,10$ & $\begin{array}{l}\text { If the Wi-Fi network is not good switch } \\
\text { to personal quota / look for a better } \\
\text { network / Change quota card or restart } \\
\text { for a better network }\end{array}$ \\
\hline
\end{tabular}




\begin{tabular}{c|c|l}
\hline 7. & 11 & $\begin{array}{l}\text { Consultation with the lecturer concerned } \\
\text { and sometimes asking for a replay }\end{array}$ \\
\hline 8. & 12 & Try your best to solve the trouble \\
\hline 9. & $13,14,15,17,18,19$ & $\begin{array}{l}\text { There is no way to solve it other than } \\
\text { going back to college offline on campus }\end{array}$ \\
\hline 10. & 20 & Try to listen well \\
\hline 11. & 22,24 & $\begin{array}{l}\text { Trying to increase the spirit even though it } \\
\text { is very difficult to concentrate }\end{array}$ \\
\hline 12. & 23 & Forcing to keep learning \\
\hline 13. & & \\
\hline
\end{tabular}

Referring to the data shown above about the ways that students do in minimizing the obstacles encountered in online listening learning, there are several ways that students can do in dealing with or minimizing the problems encountered during Listening Comprehension learning, some students continue to try to maximize connections looking for a good place for network conditions, switch to a quota network, study independently, ask lecturers or friends again, use headsets, and most students still want lectures to be done offline because there is nothing else that can clarify the information the lecturer provides if not offline.

From the data search process and finding in the first questionnaire, Balikpapan foreign language academy students have participated in English learning before with different time variations of over 3 years and $37 \%$ studying 12 years and over, the student learning experience is quite helpful in the smooth teaching and learning process This is in accordance with the opinion which says that with the length of student learning, a fairly good learning climate is formed in the learning process in the classroom (Habib, 2020). In connectionism theory, it is also stated that learning is the formation of a relationship between stimulus and response, and repetition of those experiences increases the chance of a correct response and also a repeated learning process will create a large enough opportunity. (Hestunodya, 2014) Another part of the questions asked was the importance of listening skills needed or learned and $100 \%$ percent of students stated that it was very important to learn listening skills in English. Related to the importance of listening (Maulidyah, 2017) says Listening is an important part of effective communication, the importance of listening in language learning is worth considering since when people do not listen they will never learn anything new. Due to the pandemic conditions in 2019, learning became online, this learning model also caused problems that greatly disturbed students in the learning and teaching process, because students and lecturers were not entirely ready to learn to be independent, from searches conducted, information on student problems at the foreign language academy was found. Listening comprehension learning in semesters I (one) and III (three) includes internet network, audio output is not clear, noise around, unsupported devices, vocabulary that is difficult to understand, difficult to concentrate. (Ghoneim, 2013) and (Underwood, 1990) the first problem is the speed of delivery, the speed of delivery is beyond the control of listeners. The second problem, it is not always possible for learners to have words repeated, Third the small size of the learners vocabulary frequently impedes listening comprehension. Meanwhile, (Putra, 2019) lack of listening practices and low concentration can lead the students to get confused in understanding the difficult words/phrases and distinguishing 
sentence pattern and discourse marker, and unable to keep us with the native speaker speed. With all the problems received, students make efforts to minimize these problems, including studying independently or discussing with lecturers or fellow students, hoping that teaching and learning activities can be carried out face to face so that the material provided can be easily understood and direct communication can be carried out. (Utomo et al., 2021) teaching and learning activities in the midst of the covid-19 pandemic so as not to reduce students' understanding in understanding the material presented to students. The principal makes the concept of face-to-face methods and online learning in accordance with the established health protocols. At the time of online learning, lecturers are expected not only to give tasks that make students bored, but also to creative materials such as activities that train children to be independent without the child feeling bored. Facilitate parents to ask directly to the teacher or lecturer if the given task is difficult for students to solve. Reducing materials that require students to search for themselves on the internet but provide material that is in accordance with their knowledge needs.

\section{CONCLUSIONS}

\subsection{Conclusion}

Learning activities cannot be postponed or stopped even though the situation is in a pandemic because if it is stopped then the students will experience a decrease in their enthusiasm for learning and will cause a high dropout rate in a country, from the results of a survey conducted by UNICEF it was noted that as many as $1 \%$ or 938 children aged 7 up to 18 years have dropped out of school with various problems such as lack of funds, no desire, environmental influences, working and feeling enough with the current education. With such a big risk that the government decides to do online learning, this of course requires teachers to have an effective and efficient way of transferring knowledge, including foreign language learning. The Balikpapan Foreign Language Academy has also implemented an online learning system during this pandemic, especially listening courses, from the results of data collection that some students who took listening comprehension courses had studied English for more than 7 (seven) years, but the length of time it took to learn English still encountered obstacles in learning, especially online learning, including the network that always goes up and down, audio devices that do not support so that the sound emitted becomes unclear, sounds that arise in the environment around students and lecturers, audio devices for students or lecturers that are in error, tasks that are often forgotten and there are many more problems that exist and interfere with the online learning process, the obstacles encountered by some students feel a decrease in their enthusiasm for learning and some do not feel disturbed by the situation, students continue to work efforts to minimize problems, because lectures still have to run these obstacles should not stop the lecture process, so students try to keep the internet network used to run optimally by looking for strategic places, repeating learning independently, asking a lot of lecturers or friends who understand well the material provided, use supporting tools such as headsets to still want lectures to be carried out offline, for lecturers to continue to carry out learning by trying as much as possible for students to understand well, including sending audio using whatsapp or google classroom devices, making conclusions learning outcomes, giving independent assignments and so on and students are also no less trying to stay able to learn and overcome problems during online learning, including looking for places that the internet network is quite adequate and 
uninterrupted, learn independently to repeat the material that has been given and keep the spirit in carrying out online lectures.

\subsection{Suggestions}

From the results of this study, the author hopes that it can provide benefits for improving the teaching system, especially in the listening comprehension course, and it is also hoped that all students who attend lectures in the course can minimize the problems that occur.

It is hoped that in the future learning can take place offline or with a hybrid method, if you still have to carry out online activities, it needs to be handled appropriately so that the learning process using audio can run optimally so that students can easily understand the material being studied. For network constraints that are often experienced in online learning, hopefully in the future there will be an increase because this problem cannot be separated from the provider that provides network services.

This research, of course, still needs development for the improvement and advancement of science and teaching methods, especially in listening comprehension courses, this research can be further developed in the process of how to overcome problems of lecturers or teachers in listening learning, improving listening comprehension by using learning strategies such as topdown and bottom-up strategy or research on factors for improving listening English learning. With continuous development in research, it is hoped that it can help lecturers or lecturers in carrying out the teaching and learning process well.

\section{REFERENCES}

Fika, M. (2016). Kesulitan Mahasiswa Dalam Mencapai Pembelajaran Bahasa Inggris Secara Efektif. Jurnal Pedagogia, 5. https://doi.org/10.1007/s00381-016-3174-3

Ghoneim, N. M. (2013). The Listening Comprehension Strategies Used by College Students to Cope with the Aural Problems in EFL Classes: An Analytical Study. English Language Teaching.

Habib, A. M. M. (2020). Teori Belajar Behaviorisme Albert Bandura Dan Implikasinya Dalam Pembelajaran Bahasa Arab. لسـانـL (LISANUNA): Jurnal Ilmu Bahasa Arab Dan Pembelajarannya, 10(1), 22. https://doi.org/10.22373/ls.v10i1.7803

Hestunodya. (2014). Pengulangan Sebagai Salah Satu Prinsip Pembelajaran. https://hestunodya.blogspot.com/2014/01/pengulangan-sebagai-salah-satu-prinsip.html

Kustanti, D. (2016). Kesulitan dan Solusi Pembelajaran English Reading Text. Al-Tsaqafa, Volume 13(01).

Lambert, V. a., \& Lambert, C. E. (2013). Qualitative Descriptive Research: An Acceptable Design. Pacific Rim International Journal of Nursing Research, 16(4), 255-256. http://antispam.kmutt.ac.th/index.php/PRIJNR/article/download/5805/5064

Mandarani, V. (2016). Peningkatan Kemampuan Listening Comprehension Melalui Stategi Top- 
Down dan Bottom-Up. PEDAGOGIA: Jurnal Pendidikan, 5(2), 189.

https://doi.org/10.21070/pedagogia.v5i2.250

Maulidyah, N. (2017). THE STUDENTS' PROBLEMS IN LISTENING COMPREHENSION Noor Maulidiyah A Lecturer of English Education Department at Tarbiyah and Teachers Training Faculty of IAIN Antasari Banjarmasin.

Moleong, L. (2002). Metodologi Penelitian Kualitatif. PT. Remaja Rosdakarya.

Putra, H. W. (2019). Improving the Students' Listening Comprehension through Drill Technique. Teknosastik, 16(2), 49. https://doi.org/10.33365/ts.v16i2.140

Rijali, A. (2018). Analisis Data Kualitatif Ahmad Rijali UIN Antasari Banjarmasin. 17(33), 8195.

Rusman. (2009). Pemanfaatan Internet untuk Pembelajaran : Pedoman bagi Guru. 2007.

Sugiono. (2007). Metode Penelitian Bisnis. Alfabeta.

Susanthi, I. G. A. A. D. (2021). Kendala dalam Belajar Bahasa Inggris dan Cara Mengatasinya. Linguistic Comunity Service Journal, 1(2), 64-70. https://www.ejournal.warmadewa.ac.id

Syam, U. K. (2012). the Use of Tomatis Method To Improve Students' Listening Skill. Exposure : Jurnal Pendidikan Bahasa Dan Sastra Inggris, 1(1), 104. https://doi.org/10.26618/ejpbi.v1i1.766

Underwood, M. (1990). TeachingListening. Longman.

Utomo, K. D., Soegeng, A. Y., \& ... (2021). Pemecahan Masalah Kesulitan Belajar Siswa pada Masa Pandemi Covid-19. Mimbar Pgsd ..., 9(1), 1-9. https://ejournal.undiksha.ac.id/index.php/JJPGSD/article/view/29923 